Federal Reserve Bank of Minneapolis

Research Department

\title{
Social Accounting Matrices and Applied General Equilibrium Models
}

\author{
Timothy J. Kehoe* \\ Working Paper 563 \\ Revised January 1996
}

\begin{abstract}
To illustrate the use of social accounting matrices (SAMs) in applied general equilibrium (GE) modeling, we use an aggregated SAM for the Spanish economy to calibrate a simple applied GE model. The idea is to construct artificial people - households, government, and a foreign sector - who make the same tran sactions in the equilibrium of the model economy as do their counterparts in the data. This calibration procedure can be augmented, or partially substituted for, by statistical estimation of key parameters. We show the usefulness of such a model by presenting the results of a comparative exercise that mimics the policy changes that took place in Spain during its 1986 integration into the European Community. Su bsequent data shows the model results to be remarkably accurate, especially if we account for other major shocks affected the Spanish economy in 1986.

*University of Minnesota and Federal Reserve Bank of Minneapolis. This paper draws heavily on Kehoe and Kehoe (1994) and Kehoe, Polo, and Sancho (1995). The research was sponsored by the Air Force Office of Scientific Research, Air Force Material Command, USAF under grant F49620-94-1-0461. The U.S. Government is authorized to reproduce and distribute reprints for governmental purposes notwithstanding any copyright notation thereon. The views expressed herein are those of the author and not necessarily those of the Air Force Office of Scientific Research or the U.S. Government. The views expressed herein are those of the author and not necessarily those of the Federal Reserve Bank of Minneapolis or the Federal Reserve System.
\end{abstract}




\section{Introduction}

The use of social accounting matrices (SAMs) to record all of the transactions that place in a national economy during one year has a distinguished ancestry. This ancestry can be traced back at least as far as Quesnay's (1759) tableau économique. (See Studenski 1958 and Stone's 1986 Nobel Memorial Lecture for histories of social accounting.) In the twentieth century, social accounting has been heavily influenced by the work on national income accounts by Kuznets (1937) and that on input-output matrices by Leontief (1941). The development of SAMs as they are used today began with the work by Meade and Stone (1941) for the Economic Section of the British Cabinet Office, which developed the first logically complete set of double-entry national income accounts. Subsequent work by Stone (1947) resulted in the conventions for social accounting embodied in the United Nations' $(1953,1968)$ System of National Accounts, which are currently used throughout the world.

The development of social accounting went hand-in-hand with the development of planning models that used this data. Indeed, Meade and Stone's (1941) original work was meant to provide data to aid in implementing Keynes's (1940) proposals for funding Britain's war effort during the Second World War. Stone's later work on social accounting in Britain provided data for the Cambridge Growth Model at the Department of Applied Economics. Indeed, in the hands of some users, SAMs have become economic models in and of themselves, with spread-sheet type relationships between entries. The volume edited by Pyatt and Round (1985) contains a number of illustrative examples of this sort of modeling.

An even more popular-but closely related—use of SAMs has been to provide data bases for constructing applied general equilibrium (GE) models. Like social accounting, applied GE modeling has a long and distinguished-and sometimes overlapping-ancestry. Numerical applications of general equilibrium narrowly defined began with the work of Harberger (1962) and Johansen (1960). 
Harberger used a model with two production sectors, one corporate and the other noncorporate, calibrated to U.S. data from the 1950 s, to calculate the incidence of the U.S. corporate income tax. Johansen used a model with 19 production sectors, calibrated to Norwegian data from 1950, to identify the sources of economic growth in Norway over the period 1948-53.

Work on applied GE models received a crucial stimulus from the research of Scarf (1967, 1973) on the computation of economic equilibria. Scarf developed an algorithm for calculating an equilibrium of a multisectoral GE model. Refinements of this algorithm are still used by some modelers. Probably the most significant consequences of Scarf's work, however, were to establish a close connection between applied GE research and the theoretical research of such economists as Arrow and Debreu (1954) and McKenzie (1951) on existence of equilibrium in very general models and to inspire a generation of Yale graduate students to enter the applied GE field. (Arrow and Kehoe 1994 discuss Scarf's contributions to applied GE modeling.)

Two of Scarf's most prominent students are Shoven and Whalley (1972), who developed a calibrated, multisectoral general equilibrium framework to analyze the welfare impact of government tax policy. Shoven and Whalley $(1984,1992)$ provide surveys of this work and the large literature that has followed it. Early models in the Shoven-Whalley tradition were explicitly static, studying the determination of equilibrium in a single period. Later models studied the evolution of capital stocks over time in a framework where the people in the model either solve static problems (as in Johansen's model) or, what is almost the same, where people have myopic expectations, that is, they expect current relative prices to persist in the future; see Fullerton, Shoven, and Whalley (1983) for an example of the latter approach. Ballard and Goulder (1985) developed a perfect foresight version of the Fullerton-Shoven-Whalley model.

Researchers working in the Shoven-Whalley tradition have stressed developing theoretical underpinnings for applied GE models and producing results that are meant to be compared with those 
of simpler theoretical frameworks. They have spent little effort in comparing their results with outcomes of policy changes in the world. Whalley $(1986,1988)$, for example, contends that these models are not intended to forecast the values of economic variables, but rather to provide useful insights that may help policymakers to undertake more informed, and presumably more desirable, policy actions. This line of thought has led Whalley to suggest that the concept of positive economics should be perhaps altogether abandoned in applied GE modeling. As we shall see, however, applied GE models can be used to make conditional forecasts with some accuracy.

Several other groups of researchers began using static applied GE models to do policy analysis after Shoven and Whalley (1972). One such group centered around the World Bank and focused on developing countries; a survey of its work is presented by Dervis, de Melo, and Robinson (1982). Another group has come to prominence doing policy analysis in Australia; a summary of early work by this group is given by Dixon, Parmenter, Sutton, and Vincent (1982); a more recent survey is presented by Dixon, Parmenter, Powell, and Wilcoxen (1992).

There is a large and expanding literature on multisectoral applied GE models. A recent search of the EconLit database produced references to more than 200 books and journal articles on this subject. Prominent contributors-besides those mentioned above-include Ginsburgh and Waelbroeck (1981), Jorgenson (1984), and Manne (1985). There have also been numerous collected volumes of papers on this subject: Scarf and Shoven (1984); Piggott and Whalley (1985, 1991); Srinivasan and Whalley (1986); Bergman, Jorgenson, and Zalai (1990); Taylor (1990); Don, van de Klundent, and van Sinderen (1991); and Mercenier and Srinivasan (1994).

This paper illustrates the use of SAMs in applied GE modeling. We first present an aggregated SAM for the Spanish economy in 1980, based on a disaggregated matrix constructed by Kehoe, Manresa, Polo, and Sancho (1988). Using this matrix, we calibrate a simple applied GE model. The idea is to construct artificial people—households, government, and foreign sectors-who 
make the same transactions in the equilibrium of the model economy as are observed in the SAM. This calibration procedure can be augmented, or partially substituted for, by statistical estimation of key parameters.

We show the usefulness of such an applied GE model by presenting the comparative statics exercise of Kehoe, Manresa, Noyola, Polo, and Sancho (1988) that analyzes the economic impact of the policy changes that accompanied Spain's 1986 entry into the then European Community (EC). We also present results obtained by Kehoe, Polo, and Sancho (1995), who find that the results of the model were remarkably accurate in predicting the change in relevant economic variables that occurred in Spain in 1986. This is especially true if we account for two other major shocks-a fall in international petroleum prices and a bad harvest—-that hit the Spanish economy in 1986.

\section{An Aggregated Spanish SAM}

Tables 1 and 2 present an aggregated SAM for Spain in 1980. It is based on a matrix constructed by Kehoe, Manresa, Polo, and Sancho (1988) that has a much higher degree of disaggregation and precision. The inter-industry transactions have been aggregated under the categories of three industrial sectors: primaries, manufactures, and services. These sectors are highly aggregated. The manufacturing sector, for example, lumps together such diverse goods as machinery, transportation equipment, and processed foods. The model actually used to analyze the impact on different industrial sectors of policies that accompanied Spain's entry into the EC has a finer disaggregation, as shown in Tables 5 and 6.

All quantities in Table 2 are expressed in trillions of 1980 Spanish pesetas (that is, U.S. trillions, British/Spanish billions). In 1980, the exchange rates between pesetas and U.S. dollars averaged about 72 pesetas per dollar; that between the pesetas and pounds sterling averaged about 167 pesetas per pound. The 1980 Spanish Gross Domestic Product (GDP) of 15 trillion pesetas 
reported in Tables 2 and 4, for example, corresponds to 208 billion U.S. dollars or 90 billion pounds sterling.

In a SAM, the label on a column indicates who made an expenditure, and the label on a row indicates who received it. Reading down the second column of Table 2, for example, we see that in 1980 producers of manufacturing goods in Spain purchased 1 trillion pesetas of intermediate inputs from producers of primaries and paid 2 trillion pesetas for labor inputs. Reading across the second row, we see that producers of services purchased 1 trillion pesetas of manufactures and that 2 trillion pesetas of manufactures were exported. The rows and columns of the matrix in Table 2 are ordered so that the transactions break down into blocks: producer goods, consumer goods, factors of production, institutions, the capital account, and the foreign sector.

It is worth making three observations about this SAM: First, the matrix disaggregates households using data from the Spanish household income and expenditure survey. As explained by Stone (1985), this sort of disaggregation of consumers requires a different disaggregation of consumer goods than that used for inter-industry transactions - consumers report on their purchases of food, for example, not on the complex combination of agriculture, food products, commercial services, and transportation services that are embodied in that food. The second $3 \times 3$ matrix on the top of the SAM in Table 2 shows this combination. Consumer purchases of 4 trillion pesetas of clothing, housing, and household articles, for example, translate into purchases of 1 trillion pesetas of primaries, 1 trillion pesetas of manufactures, and 2 trillion pesetas of services. Second, the SAM reported in Table 2 include an input-output matrix as a collection of submatrices. That input-output matrix is reported in Table 3. Third, the transactions reported in the SAM are also consistent with the figures in the national income and product accounts presented in Table 4, which records the Spanish GDP in 1980 as being 15 trillion pesetas. 


\section{A Simple Applied GE Model}

We construct an applied GE model by inventing artificial households, producers, a government, and foreigners who make the same transactions in the base case equilibrium of the computer economy as do their counterparts in the world. With a large amount of data (for example, a time series of SAMs), we could use statistical estimation techniques to find the parameters that characterize the people in the artificial economy (see Jorgenson 1984).

A more common method for constructing an applied GE model is to calibrate its parameters (see Mansur and Whalley 1984). Using simple functional forms, we work backward from the data in Table 2 to construct economic agents whose transactions duplicate those observed. As we explain later, statistical estimates of key parameter can easily be incorporated into this calibration procedure.

To understand the uses of this sort of model and the procedure used to calibrate it, consider a highly simplified model in which there are four consumers: a representative low-income household, a representative high-income household, the government, and the rest of the world. In this economy, eight goods are produced: primaries, manufactures, services, food, housing, consumer services, an investment good, and an export/import good. Each of these goods is produced using intermediate inputs of the other goods; the two factors of production, labor and capital; and the import good.

We assume that a consumer solves a utility maximization problem of the form

$$
\max u_{i}\left(c_{1}^{i}, \ldots, c_{8}^{i}\right)
$$

subject to

$$
\sum_{\mathrm{j}=1}^{8} \mathrm{p}_{\mathrm{j}} \mathrm{c}_{\mathrm{j}}^{\mathrm{i}} \leq \mathrm{I}^{\mathrm{i}} .
$$

In the utility function $c_{j}^{i}$ is the purchase of good $j$ by consumer $i$. The SAM tells us that consumers 1 and 2 make purchases of the consumer goods 4, 5, and 6 and the investment good 7. The government makes the purchases of good 3, services, and good 7, investment. The rest of the world 
purchases good 7, investment (this is the capital flow compensating for the Spanish trade deficit), and good 8, exports. In the budget constraint $\mathrm{p}_{\mathrm{j}}$ is the price of good $\mathrm{j}$ and the $\mathrm{I}^{\mathrm{i}}$ is the income of consumer i. Consumers 1 and 2 have after-tax income from selling the services of their labor and capital and from transfers they receive from the government,

$$
\mathrm{I}^{\mathrm{i}}=\left(1-\tau_{\mathrm{i}}\right)\left(\mathrm{w} \bar{\ell}^{\mathrm{i}}+\mathrm{rk}^{\mathrm{i}}\right)+\mathrm{T}^{\mathrm{i}}
$$

Here $\mathrm{w}$ and $\mathrm{r}$ are the wage rate and capital rental rate, $\bar{l}^{\mathrm{i}}$ and $\overline{\mathrm{k}}^{\mathrm{i}}$ are the consumer's endowments of labor and capital, $\tau_{\mathrm{i}}$ is the direct tax rate, and $\mathrm{T}^{\mathrm{i}}$ is the transfer payment. The government receives income from taxes and, if it runs a deficit, from selling bonds that are a perfect substitute for the investment good. The rest of the world receives income from selling imports and, if there is a trade surplus, from selling the investment good.

We put purchases of the investment good into the utility functions to account for the savings observed in the data. In a dynamic model, consumers save so that they can enjoy future consumption, and purchases of the investment good in one period augment the capital stock in the next. In this type of static model, however, investment is treated as another final demand for goods, like consumption. A simple form for the utility function is linear in logarithms:

$$
\mathrm{u}_{\mathrm{i}}\left(\mathrm{c}_{1}^{\mathrm{i}}, \ldots, \mathrm{c}_{8}^{\mathrm{i}}\right)=\sum_{\mathrm{j}=1}^{8} \theta_{\mathrm{j}}^{\mathrm{i}} \log \mathrm{c}_{\mathrm{j}}^{\mathrm{i}}
$$

Here, the numbers $\theta_{\mathrm{j}}^{\mathrm{i}}$ are nonnegative parameters, the calibration of which we describe later.

We assume that domestic output of each of the eight produced goods has a constant-returns production function that combines intermediate inputs in fixed proportions and labor and capital with substitution possibilities governed by a Cobb-Douglas production function of the form $\beta \mathrm{k}^{\alpha} \ell^{1-\alpha}$. Subsequently, we explain how this domestic output combines with inputs. The general form of the domestic production function is 


$$
y_{j d}=\min \left(x_{1 j} / a_{1 j}, \ldots, x_{8 j} / a_{8 j}, \beta_{j} k_{j} \alpha_{j} l_{j}^{1-\alpha_{j}}\right) .
$$

Here, $x_{i j}$ is the intermediate input of good $i$ used in the production of good $j$; $a_{i j}$ is the amount of good $\mathrm{i}$ required to produce one unit of $\operatorname{good} \mathrm{j}$; and $\mathrm{a}_{\mathrm{ij}}, \beta_{\mathrm{j}}$, and $\alpha_{\mathrm{j}}$ are parameters to be calibrated.

Not every good is used in the production of every other good. We handle this problem by dropping the corresponding entry from the production function, rather than by adopting complicated conventions about dividing by zero and so on. The production function for manufactures, for example, is

$$
\mathrm{y}_{2 \mathrm{~d}}=\min \left(\mathrm{x}_{12} / \mathrm{a}_{12}, \mathrm{x}_{22} / \mathrm{a}_{22}, \mathrm{x}_{32} / \mathrm{a}_{32}, \beta_{2} \mathrm{k}_{2}^{\left.\alpha_{2} l_{2}^{1-\alpha_{2}}\right) .}\right.
$$

Both $\mathrm{x}_{42}$ and $\mathrm{x}_{72}$, for example, are omitted here because Table 2 shows that neither the food nor the investment good is used in the production of manufactures. Similarly, the production function for food is

$$
\mathrm{y}_{6 \mathrm{~d}}=\min \left(\mathrm{x}_{14} / \mathrm{a}_{14}, \mathrm{x}_{24} / \mathrm{a}_{24}, \mathrm{x}_{34} / \mathrm{a}_{34}\right) .
$$

Both $\mathrm{k}_{4}$ and $\ell_{4}$ are omitted here because, in keeping with the accounting conventions used in Table 2, we consider food to be produced by selling a combination of the producer goods rather than by any process that involves labor and capital directly: commercial markups, transportation costs, and so on, are already included in the intermediate input of services in the food column.

We assume that producers minimize costs and earn zero after-tax profits. Since this assumption implies that producers never waste inputs, we can write the domestic production function for manufactures, for example, as

$$
\mathrm{y}_{2 \mathrm{~d}}=\mathrm{x}_{12} / \mathrm{a}_{12}=\mathrm{x}_{22} / \mathrm{a}_{22}=\mathrm{x}_{32} / \mathrm{a}_{32}=\beta_{2} \mathrm{k}_{2}^{\alpha_{2}} \ell_{2}^{1-\alpha_{2}}
$$


Cost minimization further implies that $\mathrm{k}_{2}, \mathrm{\ell}_{2}$ solve

$$
\min \mathrm{wl}_{2}+\mathrm{rk}_{2}
$$

subject to

$$
\beta_{2} \mathrm{k}_{2}^{\alpha_{2}} \ell_{2}^{1-\alpha_{2}} \geq \mathrm{y}_{2 \mathrm{~d}}
$$

Again, $\mathrm{w}$ is the wage rate, and $\mathrm{r}$ is the capital rental rate. Our assumption that after-tax profits equal zero is

$$
\left(1-\mathrm{t}_{2}\right) \mathrm{p}_{2} \mathrm{y}_{2 \mathrm{~d}}-\sum_{\mathrm{i}=1}^{8} \mathrm{p}_{\mathrm{i}} \mathrm{a}_{\mathrm{i} 2} \mathrm{y}_{2}-\mathrm{w} \ell_{2}-\mathrm{rk}_{2}=0
$$

Here, $\mathrm{t}_{2}$ is the indirect tax rate on sales of manufactures.

In our model, as in many applied GE models, we distinguish goods by industry and by country of origin. Thus, for example, a Spanish-produced automobile is a different good from a German-produced automobile-a close but imperfect substitute. This specification, named the Armington (1969) specification after the economist who invented it, has three advantages over obvious alternatives for matching the model to data on trade flows. One is that it accounts for the large amount of cross-hauling present in the data, where a country both imports and exports goods of the same product category. In a model where goods are homogeneous, there is no reason for cross-hauling. Another advantage of this specification is that it explains the empirical observation that even at a very disaggregated level, most countries produce goods in all product categories. In models where goods are not distinguished by country of origin and produced goods exceed factors of production, countries typically specialize in the production of a limited number of goods. Still another advantage of the Armington specification is that it allows for differing degrees of substitution among domestic and imported goods across different products and allows for changes in the relative prices of different imported goods. Empirical studies indicate that both of these phenomena are found in time series data. (See, for example, Shiells, Stern, and Deardorff 1986.) Neither is possible in a 
model that aggregates all imports together or in a model that treats domestic and imported goods as perfect substitutes.

To implement the Armington specification we need a SAM in which imports are classified by the sector that produces them, the sector of origin, and not by the sector that purchases them, the sector of destination. SAMs can be arranged according to either convention: the SAM in Table 2 follows the sector of origin convention; thus, the 2 in column 2, row 13 indicates that Spain imported 2 trillion pesetas of manufactures in 1980, not that the Spanish manufacturing sector purchased 2 trillion pesetas of imported goods of all sorts. To keep things simple, we assume that domestic output is combined with imports to produce a composite good according to a Cobb-Douglas Armington aggregator. Later, we explain how this can be generalized. The composite manufactured good is the Cobb-Douglas aggregate

$$
\mathrm{y}_{2}=\gamma_{2} \mathrm{y}_{2 \mathrm{~d}}^{\delta_{2}} \mathrm{x}_{28}^{1-\delta_{2}}
$$

Here, $\mathrm{y}_{2}$ is the aggregate of manufactures, $\mathrm{y}_{2 \mathrm{~d}}$ is domestic output specified above, and $\mathrm{x}_{28}$ is imports of manufactures. We can think of imports as being produced by an international trade activity that uses exports as inputs:

$$
\mathrm{y}_{8}=\min \left[\mathrm{x}_{18} / \mathrm{a}_{18}, \mathrm{x}_{28} / \mathrm{a}_{28}\right]
$$

We require that this activity make zero profits, thus determining the relative price of imports. As explained below, however, we do not require balanced trade.

The behavior of the government and the rest of the world needs to be carefully specified. The government, for example, derives income from direct and indirect taxes. (In the disaggregated model it also receives tariff revenues and capital income although these are so small that they have been rounded to zero here.) It uses this income to purchase government services and investment and to 
make transfers to consumers. We specify these transfers as fixed in terms of a relevant consumer price index:

$$
\mathrm{T}^{\mathrm{i}}=\left(\sum_{\mathrm{j}=1}^{8} \theta_{\mathrm{j}} \mathrm{p}_{\mathrm{j}}\right) \overline{\mathrm{T}}^{\mathrm{i}}
$$

where $\theta_{\mathrm{j}}=\left(\theta_{\mathrm{j}}^{1} \mathrm{I}^{1}+\theta_{\mathrm{j}}^{2} \mathrm{I}^{2}\right) /\left(\mathrm{I}^{1}+\mathrm{I}^{2}\right)$ is the total consumption share of good $\mathrm{j}$ and $\overline{\mathrm{T}}^{\mathrm{i}}$ is a constant. (In the more detailed model actually used for policy evaluation in Spain, transfers are modeled in far more detail, including health benefits that depend on the price of medical services and unemployment benefits that depend on an endogenously determined unemployment rate.)

The difference between total revenues and expenditures determines the public surplus or deficit. The model satisfies the macroeconomic identity that private savings is equal to private investment plus the government deficit minus the trade deficit with the rest of the world.

The model allows some flexibility in choosing the variables that are exogenous and endogenous. The government deficit, for example, can be endogenous or exogenous. In the first case, the activity level of the government is fixed, while in the second the activity level is endogenous. This flexibility allows us to answer two different questions: What would be the government deficit when the government activity level is arbitrarily fixed? and, What would be the variation needed in the government activity level to achieve a given government deficit target?

We also have the option of making exports to the rest of the world exogenous or endogenous. If exports are exogenously fixed, for example, then, since imports are endogenously determined, so is the trade deficit. In contrast, if the trade deficit is arbitrarily fixed, then exports are endogenous. We, therefore, have two options: to make the government deficit endogenous or exogenous, and to make the trade deficit endogenous or exogenous. There are potentially, therefore, four different 
macroeconomic closure rules. There are additional possibilities for macroeconomic closure that involve making investment exogenous; we do not consider such closure rules here.

All these elements of the model economy are linked by the concept of equilibrium. An equilibrium is specified by listing values for all of the endogenous variables in the model: a price for each of the produced goods $\hat{\mathrm{p}}_{\mathrm{j}}$, a price for domestic production of each of the goods $\hat{\mathrm{p}}_{\mathrm{jd}}$, a level of consumption for each good by each consumer $\hat{c}_{j}^{i}$, a wage rate $\hat{w}$, a capital rental rate $\hat{r}$, a production plan for each of the produced goods $\left(\hat{\mathrm{y}}_{\mathrm{j}}, \hat{\mathrm{x}}_{1 \mathrm{j}}, \ldots, \hat{\mathrm{x}}_{8 \mathrm{j}}, \hat{\mathrm{k}}_{\mathrm{j}}, \hat{\ell}_{\mathrm{j}}\right)$, a level of government tax receipts $\hat{\mathrm{R}}$, transfer payments to consumers $\hat{\mathrm{T}}^{\mathrm{i}}$, a government deficit $\hat{\mathrm{G} D}$, and a trade deficit $\hat{\mathrm{T} D}$. To be an equilibrium, such a list must satisfy the following properties:

- The consumption vector $\left(\hat{\mathrm{c}}_{1}^{\mathrm{i}}, \ldots, \hat{\mathrm{c}}_{8}^{\mathrm{i}}\right)$ solves the utility-maximization problem of consumer $\mathrm{i}$.

- The production plan $\left(\hat{\mathrm{y}}_{\mathrm{j}}, \hat{\mathrm{x}}_{1 \mathrm{j}}, \ldots, \mathrm{x}_{8 \mathrm{j}}, \hat{\mathrm{k}}_{\mathrm{j}}, \hat{\ell}_{\mathrm{j}}\right)$ minimizes costs subject to the feasibility constraints and earns zero after-tax profits.

- Supply equals demand in the market for each produced good:

$$
\begin{aligned}
& \hat{y}_{j}=\sum_{i=1}^{4} \hat{c}_{j}^{i}+\sum_{\ell=1}^{8} \hat{x}_{j \ell} . \\
& \text { for } j=1, \ldots, 8 .
\end{aligned}
$$

- Supply equals demand in each factor market:

$$
\begin{aligned}
& \bar{l}^{1}+\bar{l}^{2}=\sum_{\mathrm{j}=1}^{8} \hat{\ell}_{\mathrm{j}} \\
& \mathrm{k}^{-1}+\mathrm{k}^{-2}=\sum_{\mathrm{j}=1}^{8} \hat{\mathrm{k}}_{\mathrm{j}} .
\end{aligned}
$$

- The tax receipts equal total taxes paid:

$$
\hat{\mathrm{R}}=\sum_{\mathrm{i}=1}^{2} \tau_{\mathrm{i}}\left(\hat{\mathrm{w}} \overline{\mathrm{l}}^{\mathrm{i}}+\hat{\mathrm{r}} \overline{\mathrm{k}}^{\mathrm{i}}\right)+\sum_{\mathrm{j}=1}^{8} \mathrm{t}_{\mathrm{j}} \hat{\mathrm{p}}_{\mathrm{j}} \hat{\mathrm{y}}_{\mathrm{j}} .
$$


- Transfer payments are fixed in real terms:

$$
\hat{\mathrm{T}}^{\mathrm{i}}=\left(\sum_{\mathrm{j}=1}^{8} \theta_{\mathrm{j}} \hat{\mathrm{p}}_{\mathrm{j}}\right) \overline{\mathrm{T}}^{\mathrm{i}}
$$

- The government satisfies its budget constraint:

$$
\hat{\mathrm{p}}_{3} \hat{\mathrm{c}}_{3}^{3}+\hat{\mathrm{p}}_{7}^{3} \hat{\mathrm{c}}_{7}^{3}+\hat{\mathrm{T}}^{1}+\hat{\mathrm{T}}^{2}=\hat{\mathrm{R}}+\hat{\mathrm{G} D} \text {. }
$$

If the government deficit is fixed in real terms- $\hat{\mathrm{GD}}=\left(\sum_{\mathrm{j}=1}^{8} \theta_{\mathrm{j}}^{3} \hat{\mathrm{p}}_{\mathrm{j}}\right) \overline{\mathrm{GD}}$ - then government spending $\hat{\mathrm{c}}_{3}^{3}$, $\hat{\mathrm{c}}_{7}^{3}$ varies endogenously. If government spending is fixed $-\hat{\mathrm{c}}_{3}^{3}=\overline{\mathrm{c}}_{3}^{3}$ and $\hat{\mathrm{c}}_{7}^{3}=\overline{\mathrm{c}}_{7}^{3}$-then the government deficit varies endogenously.

- The rest of the world satisfies its budget constraint:

$$
\hat{\mathrm{T} D}=\hat{\mathrm{p}}_{7} \hat{\mathrm{c}}_{7}^{4}=\hat{\mathrm{p}}_{8}\left(\hat{\mathrm{y}}_{8}-\sum_{\mathrm{j}=1}^{8} \hat{\mathrm{x}}_{8 \mathrm{j}}\right)
$$

If the trade deficit is fixed $-\hat{c}_{7}^{4}=\bar{c}_{7}^{4}-$ then exports $\hat{y}_{8}$ vary. If exports are fixed $-\hat{y}_{8}=\bar{y}_{8}-$ then the trade deficit varies endogenously.

\section{Calibration and Simulation}

We calibrate the parameters of the model economy so that the equilibrium reproduces the transactions observed in the SAM. We start with the households. Table 2 reports that the highincome household, for example, receives a factor income of 7 (trillion pesetas) -2 in wages and salaries from selling labor services and 5 from other factor payments. As is standard practice in this sort of work, we aggregate these other factors into a single factor called capital. Table 2 also reports that this consumer pays 1 in direct taxes, leaving a disposable income of 6 . Of this disposable income, 5 is spent on consumption and the residual, 1, is saved. This consumer receives no significant transfers from the government, although the representative low-income household does. 
If we use calculus to solve the consumer's problem, we obtain

$$
\mathrm{c}_{\mathrm{j}}^{2}=\theta_{\mathrm{j}}^{2}\left(1-\tau_{2}\right)\left(\mathrm{w} \bar{\ell}^{2}+\mathrm{r} \overline{\mathrm{k}}^{2}\right) / \mathrm{p}_{\mathrm{j}}
$$

(We have normalized the parameters $\theta_{\mathrm{j}}^{2}$ to sum to one.) We could think of each of the goods as being measured in some type of natural unit: primaries in terms of liters, for example, or labor services in terms of hours. Let us choose different physical units for the goods, such that one unit of each good is worth 1 trillion 1980 pesetas. This choice of units is already implicit in the construction of Table 2, where, for example, grapes and oranges have been aggregated into the primaries good. One advantage of these units is that we can calibrate the prices $p_{j}$, the wage $w$, and the capital rental rate $r$ to all equal one in the base case equilibrium. (Think of these variables as price indices, which are naturally set equal to one in the base case.)

The calibration is now straightforward. Since we know that labor income is 2, we calibrate $\bar{\ell}^{2}=2$; since we know that capital income is 5 , we calibrate $\overline{\mathrm{k}}^{2}=5$; and since we know that direct tax payment on private income of 7 is 1 , we calibrate $\tau_{2}=1 / 7$. Of the total after-tax income of $6=$ $\left(1-\tau_{2}\right)\left(w \bar{l}^{2}+r \bar{k}^{2}\right)$, we know that 1 is spent on food. We therefore calibrate $\theta_{1}^{2}=1 / 6$, for example. Similarly, we calibrate $\theta_{3}^{2}=2 / 6$ to get the consumer to spend 2 on housing in the base case equilibrium and $\theta_{7}^{2}=1 / 6$ to get the consumer to save 1 .

The calibration of the unit input requirements $\mathrm{a}_{\mathrm{ij}}$ in the production functions is equally easy. Since we know that 1 unit of primaries are required to produce 10 units of domestic production manufactures, we calibrate $a_{12}=1 / 10$. Calibrating the Cobb-Douglas function that describes how labor and capital are combined to produce value added is slightly more complicated. If we choose inputs of labor and capital to minimize costs, we know that the ratio of the marginal products should equal the factor price ratio:

$$
\left(1-\alpha_{2}\right) \mathrm{k}_{2} /\left(\alpha_{2} \ell_{2}\right)=\mathrm{w} / \mathrm{r}
$$


Since we want $\mathrm{k}_{2}=1$ and $\ell_{2}=2$ in the base case equilibrium and we have chosen units so that $\mathrm{w}=$ $r=1$, we calibrate $\alpha_{2}=1 / 3$. Inserting this value for $\alpha_{2}$ into the Cobb-Douglas production function along with the observed values of labor, capital, and output, we obtain

$$
\beta_{2}=\mathrm{y}_{2 \mathrm{~d}} /\left(\mathrm{k}_{2}^{\alpha_{2}} \ell_{2}^{1-\alpha_{2}}\right)=10(2)^{-2 / 3} .
$$

Since producers of manufactures pay indirect taxes of 1 on total sales of 10 , we calibrate the indirect tax rate $t_{2}=1 / 10$.

We calibrate the Armington aggregator for manufactures using the same procedure: The condition that the ratio of marginal products should equal the price ratio,

$$
\left(1-\delta_{2}\right) \mathrm{y}_{2 \mathrm{~d}} /\left(\delta_{2} \mathrm{x}_{28}\right)=\mathrm{p}_{8} / \mathrm{p}_{2 \mathrm{~d}}
$$

implies that $\delta_{2}=10 / 12$. Inserting this value of $\delta_{2}$ and the observed values of $\mathrm{y}_{2 \mathrm{~d}}$ and $\mathrm{x}_{28}$ into the Armington aggregator, we obtain

$$
\gamma_{2}=\mathrm{y}_{2} /\left(\mathrm{y}_{2 \mathrm{~d}}^{\delta_{2}} \mathrm{x}_{28}^{1-\delta_{2}}\right)=12(10)^{-10 / 12}(2)^{-2 / 12} .
$$

We can calibrate the production functions for other sectors similarly. The domestic production function for primaries, for example, is

$$
\mathrm{y}_{1 \mathrm{~d}}=(5 / 2) \mathrm{x}_{11}=5 \mathrm{x}_{21}=(5 / 2) \mathrm{k}_{1}^{1 / 2} \ell_{1}^{1 / 2}
$$

The Armington aggregator is

$$
\mathrm{y}_{1}=6(5)^{-5 / 6} \mathrm{y}_{1 \mathrm{~d}}^{5 / 6} \mathrm{x}_{18}^{1 / 6}
$$

The production function for housing is simply

$$
\mathrm{y}_{5}=4 \mathrm{x}_{15}=4 \mathrm{x}_{25}=2 \mathrm{x}_{35} \text {. }
$$

If we calibrate the model as above, we can use it to evaluate a change in government policy. We simply change a tax parameter, say $t_{2}$, and then calculate the new equilibrium. In general, the 
values of all of the endogenous variables change, and reporting on how some of them change is informative. When we report on the prices of produced goods and factors, we need to be explicit about the normalization. Like any general equilibrium model, this model allows for an arbitrary choice of a numeraire, that is, the unit in terms of which all values are expressed. (Looking at the definition of equilibrium, we see that multiplying $\hat{\mathrm{p}}_{\mathrm{j}}, \hat{\mathrm{p}}_{\mathrm{j} d}, \hat{\mathrm{w}}, \hat{\mathrm{r}}, \hat{\mathrm{R}}, \hat{\mathrm{T}}^{\mathrm{i}}, \hat{\mathrm{G} D}$, and $\hat{\mathrm{T} D}$ by the same positive constant still results in an equilibrium.) A typical practice is to normalize prices so that a certain price index remains constant. We could, for example, normalize prices according to a price index based on consumption weights,

$$
\sum_{\mathrm{j}=1}^{8} \theta_{\mathrm{j}} \mathrm{p}_{\mathrm{j}}=1
$$

Changes in the wage rate would then be termed changes in the real wage rate.

One of the most interesting results to report is how consumer welfare changes. Since utility is expressed in no natural units, economists often choose to measure welfare using an index based on income. A common measure of welfare is how much income the consumer would need, when faced with the base case prices, to achieve the same level of utility as in the simulation. Changes in this measure of welfare are called the equivalent variation.

In calibrating both the consumer and the producers in our simple model, we have used either Cobb-Douglas or fixed-proportions functions, and therefore all elasticities of substitution are equal to one or infinity. (The utility function is the logarithm of a Cobb-Douglas function.) If information is available on elasticities of substitution in consumption or production, however, it can easily be incorporated into the calibration procedure. Suppose, for example, that we have information from econometric estimates that the elasticity of substitution in consumption for high-income households is $1 / 2$. Then we need to calibrate the constant elasticity of substitution utility function 


$$
\mathrm{u}_{2}\left(\mathrm{c}_{1}^{2}, \ldots, \mathrm{c}_{8}^{2}\right)=\sigma_{2} \sum_{\mathrm{j}=1}^{8} \theta_{\mathrm{j}}^{2}\left(\left(\mathrm{c}_{\mathrm{j}}^{2}\right)^{1-1 / \sigma_{2}}-1\right) /\left(1-\sigma_{2}\right)
$$

where $\sigma_{2}=1 / 2$ is the elasticity of substitution. Again, we calibrate by working backward from the solution to the utility-maximization problem,

$$
c_{j}^{2}=\left(\theta_{j}^{2}\right)^{\sigma_{2}}\left(1-\tau_{2}\right)\left(w \bar{\ell}^{2}+r \bar{k}^{2}\right) /\left(p_{j}^{\sigma_{2}} \sum_{\ell=1}^{8}\left(\theta_{\ell}^{2}\right)^{\sigma_{2}} p_{\ell}^{1-\sigma_{2}}\right)
$$

We obtain, for example, the parameter for food $\theta_{1}^{2}=1 / 10$ and the parameter for housing $\theta_{2}^{2}=4 / 10$.

Similarly, suppose that we have evidence that the elasticity of substitution between domestic manufactures and imported manufactures in the Armington aggregator is $3 / 2$ :

$$
\mathrm{y}_{2}=\gamma_{2}\left[\delta_{2} \mathrm{y}_{2 \mathrm{~d}}^{1-1 / \rho_{2}}+\left(1-\delta_{2}\right) \mathrm{x}_{28}^{1-1 / \rho_{2}}\right]^{\rho_{2} /\left(\rho_{2}-1\right)}
$$

Solving the problem of minimizing $\mathrm{p}_{2 \mathrm{~d}} \mathrm{y}_{2 \mathrm{~d}}+\mathrm{p}_{8} \mathrm{x}_{28}$ subject to obtaining total output of $\mathrm{y}_{2}$ and inserting $\rho_{2}=3 / 2, \mathrm{y}_{2}=12, \mathrm{y}_{2 \mathrm{~d}}=10, \mathrm{x}_{28}=2$, and $\mathrm{p}_{2 \mathrm{~d}}=\mathrm{p}_{8}=1$, we can calibrate $\delta_{2}=5^{2 / 3} /\left(1+5^{2 / 3}\right)$ and $\gamma_{2}=$ $\left(1+5^{2 / 3}\right)^{3} / 36$

Even if we allow for more flexible functional forms, the model that we have described is highly simplified. In practice, applied GE models allow more disaggregation, more institutional details, and some market imperfections. Models used in policy analysis typically include many more production sectors. Factors of production may also be disaggregated. For example, labor might be broken down by skill level. Unfortunately, data restrictions usually prevent any simple breakdown of the aggregate capital input. In models that focus on public finance issues, more detail usually goes into specifying government tax, transfer, and subsidy systems.

A market imperfection often built into a static applied GE model is in the labor market. The real wage, specified in terms of an index of other prices, is typically modeled as being downwardly rigid. Changes in the demand for labor result in varying rates of unemployment. If demand for labor 
rises so much that full employment occurs, the real wage then rises so that supply is equal to demand (see Kehoe and Serra-Puche 1983). Another possibility is to fix the return to capital. Then the interpretation involves not unemployment of capital but rather international capital flows. If demand for capital rises, an inflow from the rest of the world occurs. If demand for capital falls, an outflow occurs.

The simple model that we have described has constant returns in production and perfect competition among producers. This was the dominant model in early applied GE analyses of trade policy (see, for example, Srinivasan and Whalley 1986). Over the past decade, however, there has been a trend toward incorporating such phenomena as increasing returns, imperfect competition and product differentiation in applied work on trade policy.

The first applied GE model to incorporate increasing returns and imperfect competition was developed by Harris (1984) to analyze the impact on Canada of the then-proposed U.S.-Canada Free Trade Agreement. Harris (1984) and Cox and Harris (1985) show that by incorporating increasing returns and imperfect competition into some industrial sectors of an applied GE model, they can capture the gains from specialization and access to larger markets for a relatively small economy like Canada. This research played an important role in the political debate in Canada leading up to approval of the agreement. Such models also played an important role in the political debate leading up to the approval of the North American Free Trade Agreement (see Kehoe and Kehoe 1995 for a survey).

\section{The Applied GE Model of Spain}

In 1985-86 a team at the Universitat Autònoma de Barcelona constructed a disaggregated SAM of the Spanish economy and used it to calibrate an applied GE model of the Spanish economy. This model was used to analyze the impact on the Spanish economy of the fiscal reform implemented 
on 1 January 1986, to accompany Spain's entry into the EC. The principal ingredient of these reforms was the introduction of a value-added tax (VAT) on consumption to replace a complex range of indirect taxes, including a turnover tax applied at every stage of the production process. The results obtained in this analysis have been issued as working papers or published in a variety of outlets (see Kehoe, Manresa, Noyola, Polo, Sancho, and Serra-Puche 1985a, 1986a, 1986b; Kehoe, Manresa, Noyola, Polo, and Sancho 1988; and Kehoe, Manresa, Polo, and Sancho 1989).

Using recently published data, Kehoe, Polo, and Sancho (1995) compare the results generated by the model to the changes that actually occurred in Spain during the period 1985-86. They find that the model performed well in predicting the changes that actually occurred. This is particularly true when they incorporate two major exogenous shocks that hit the Spanish economy in 1986: a sharp fall in the price of petroleum imports and a decline in productivity in the agricultural sector due mostly to weather conditions. The major difference between the simple applied GE model presented in the previous section and that used to analyze the 1986 policy changes is the level of disaggregation: the disaggregated model has 12 production sectors, rather than 3 , and 9 consumption goods, rather than 3. Furthermore, there are 3 factors of production, rather than 2; labor is broken down by two skill levels. (All of these sectors are listed in Table 5.) In addition, the institutions are disaggregated: There are 8 representative households, rather than 2 , and the rest of the world has been disaggregated into the rest of the EC and the non-EC rest of the world. (See Table 6.)

The other significant difference between the simple model and that used to analyze the 1986 policy changes is the modeling of the labor market. Labor demand is determined by producers to minimize costs and to meet demand for goods. Unemployment arises when the induced demand for labor is not enough to hire all labor supplied by workers. We assume that workers, or unions, fix the real wage and that all labor available is supplied at this wage, although not all is demanded. The 
real wage fixed depends on the unemployment rate, so that, in equilibrium, the following condition is satisfied in each of the two labor markets:

$$
\omega_{\mathrm{i}}=\left[\left(1-\mathrm{u}_{\mathrm{i}}\right) /\left(1-\overline{\mathrm{u}}_{\mathrm{i}}\right)\right]^{1 / \beta} .
$$

Here $\omega_{\mathrm{i}}$ is the real wage, the nominal wage divided by an appropriate consumer price index, for either unskilled labor or skilled labor; $\mathrm{u}_{\mathrm{i}}$ is the unemployment rate in the corresponding labor market; $\overline{\mathrm{u}}_{\mathrm{i}}$ is the corresponding benchmark unemployment rate; and $\beta$ is a nonnegative parameter that measures the sensitivity of real wages to unemployment. (There is, of course, another interpretation of this specification in terms of an elastic supply of labor.)

In the simulation results reported in the next section, $\beta$ is chosen to be 1.5 , following Andrés, Dolado, Molinas, Sebastián, and Zabalza (1988). Sensitivity analysis by Kehoe, Polo, and Sancho (1995) show that the central results of the simulations of the 1986 policy changes are not sensitive to this choice, as opposed to the choices of fixing a real wage index and letting unemployment vary or of fixing unemployment and letting wages vary. They also show that the results are not very sensitive to the choice of the macroeconomic closure rule discussed previously.

\section{Comparisons With Actual Data 1985-86}

Spain's 1986 entry into the European Community was accompanied by two major government policy reforms. The first, and most significant, policy reform introduced a consumption value added tax to replace the previous indirect tax system. The second policy reform reduced trade barriers against imports from other EC countries. In contrast with the fiscal policy reform, which took place immediately, the trade policy reform was scheduled to be phased in gradually over six years. The part of the reform that took place in 1986 mostly involved changes in tariff rates. Kehoe et al. (1985a, 1986a, 1986b, 1988, 1989) incorporate the tax and tariff parameters that correspond to both these policy reforms into the model described in the previous section. It should be stressed, however, 
that the parameter changes involved in the tax reform are far larger than those involved in the trade reform.

In this section we confront the results generated by the model with the data that describe the changes that actually took place in the Spanish economy during the period 1985-86. It is changes over a one- or two-year time horizon that Kehoe, Polo, and Sancho (1995) argue that this type of model can capture. On one hand, it can be argued that this time horizon is long enough so that there can be enough gestation or depreciation of capital stocks in each sector to justify assuming mobility of capital, at least as long as changes in capital utilization by sector are less than, say, 10 percent. On the other hand, it can be argued that this time horizon is short enough to justify ignoring secular trends and the intersectoral impact of changes in the growth rate.

As we have mentioned, the model was not designed to predict changes in inflation or in the growth rate. Consequently, in reporting both the simulation results and the actual data, we deflate by an appropriate price or output index. In the case of consumer prices and industrial activity levels, this procedure produces changes whose weighted average is zero. Dividing consumer prices by a consumer price index based on consumption expenditure shares by sector, for example, produces changes that sum to zero when weighted by these expenditure shares. Similarly, we obtain changes in industrial activity levels that sum to zero when weighted by value added shares by sector. In the case of producer prices, however, prices are normalized using the consumer price index rather than by a producer price index. Although this treatment of producer prices is somewhat asymmetric, it is useful because it makes it easy to compare the changes in the relative prices of consumer goods and producer goods. The change in the producer price index relative to that in the consumer price index can be recovered by summing the changes in producer prices weighted by value of production shares by sector. In all three cases, the weights used in the different indices are taken from the 1980 SAM constructed by Kehoe, Manresa, Polo, and Sancho (1988) that provides the database for the 
model. Since the model has been calibrated to a different year than the year in which the tax reform took place, the choice of weights is somewhat arbitrary. Fortunately, calculations not reported here indicate that the results are not sensitive to this choice.

Tables 7-10 present the actual changes that occurred in the Spanish economy over the period 1985-86 in terms of consumer prices, producer prices, activity levels, and macroeconomic aggregates. Because of limited data on the changes that actually took place in 1986, we report changes in producer prices and activity levels for only a subset of producer prices and activity levels. Examining the actual changes that took place over 1985-86, we see a substantial increase in indirect tax rates. This increase manifests itself in the sharp decline in the relative prices of producer goods, reported in the first column of Table 8, compared to those of consumer goods, reported in the first column of Table 7. This change in relative prices is to be expected since the VAT largely exempts producer goods from taxes. The increase in indirect taxes can also be seen in the changes in macroeconomic variables reported in the second column of Table 10, where indirect tax revenues increase as a percentage of GDP and private consumption falls. We also see in Table 10 that tariff revenue falls in 1986 as a percentage of GDP. The results presented in the second columns of Tables 7 and 8 and the fourth column of Table 10 show that these patterns are captured by the model when it simulates the policy changes that took place in 1986.

Comparing the first column in Table 7 with the second column, we see that the model does poorly in tracking the changes that actually took place in two large sectors, food and transportation. The reasons for this should be readily apparent to observers of the Spanish economy. In 1986 food prices rose sharply because of a poor harvest, and gasoline prices fell sharply because of both an appreciation of the peseta against the dollar and a fall in the dollar price of petroleum. The final column of Table 7 reports the results of a simulation where we take these two exogenous shocks into account in the simplest possible ways: We reduce the ratio of output to inputs in the agricultural 
production sector by 7.73 percent. This number is the reduction in the ratio of an index of output to an index of intermediate inputs in agriculture from 1985 to 1986, taken from the Anuario de Estadística Agraria, 1987. We also reduce the price of energy by 47.60 percent. This number is the fall in the price index of energy imports from 1985 to 1986, taken from the Boletin Trimestral de Coyuntura, Septiembre 1990. (See Kehoe, Polo, and Sancho 1995 for details.)

In comparing the results of the model with the data we report two measures of goodness of prediction, each of which implicitly compares the match between the model prediction and the actual change with the match between the prediction of no change and the actual change. The first is the weighted correlation coefficient:

$$
r=\sum_{i=1}^{n} \alpha_{i}^{2} y_{i} \hat{y}_{i} /\left(\sum_{i=1}^{n} \alpha_{i}^{2} y_{i}^{2} \sum_{i=1}^{n} \alpha_{i}^{2} \hat{y}_{i}^{2}\right)^{1 / 2}
$$

Here $\alpha_{i}$ the weight measuring the relative size of sector $i ; y_{i}$ is the actual change in sector $i$; and $\hat{y}_{i}$ is the predicted change. A high correlation coefficient rewards predictions that have the right signs and relative magnitudes. It does not take into account the absolute magnitudes of changes. The second measure of goodness of prediction that we report is the weighted prediction $\mathrm{R}^{2}$ :

$$
\mathrm{R}^{2}=1-\sum_{\mathrm{i}=1}^{\mathrm{n}} \alpha_{\mathrm{i}}^{2}\left(\mathrm{y}_{\mathrm{i}}-\hat{\mathrm{y}}_{\mathrm{i}}\right)^{2} /\left(\sum_{\mathrm{i}=1}^{\mathrm{n}} \alpha_{\mathrm{i}}^{2} \mathrm{y}_{\mathrm{i}}^{2}\right)
$$

A high $\mathrm{R}^{2}$ rewards small weighted mean squared error in prediction. Although this measure has the advantage of taking into account absolute magnitudes of changes, it has the disadvantages of being asymmetric in $y_{i}$ and $\hat{y}_{i}$ and of heavily penalizing predictions that are correct in signs and relative magnitude but too large. (The $\mathrm{R}^{2}$ reported in the tables can be thought of as that obtained from the regression: 


$$
\left(\alpha_{i} y_{i}\right)=a+b\left(\alpha_{i} \hat{y}_{i}\right)+u_{i}
$$

where $\mathrm{a}$ is constrained to be 0 and $\mathrm{b}$ is constrained to be 1.)

Once the exogenous shocks are incorporated into the model, it performs very well in accounting for the changes that actually took place in consumer prices. The correlation of the changes in the first column with those in the fifth, weighted in each case by 1980 consumption shares, is 0.936 . The prediction $\mathrm{R}^{2}$ is 0.657 ; in other words, by simulating the introduction of the VAT and the shocks to agricultural productivity and petroleum prices, the model is able to account for almost two thirds of the variation in relative prices that actually took place. It is important to notice that a substantial amount of variation did, in fact, take place.

A comparison of the final three columns of Table 7 shows that accounting for both the policy changes and the exogenous shocks that occurred in 1986 is essential for the model to obtain these results. Incorporating the exogenous shocks separately produces changes in relative prices that have a lower weighted correlation coefficient with the changes that actually took place in $1986,0.872$, and a substantially lower prediction $\mathrm{R}^{2}, 0.226$.

The performance of the model in tracking producer prices and activity levels, reported in Tables 8 and 9 is not as impressive as that for consumer prices. The model without adjustments underestimates the relative changes in producer prices that took place; the model with adjustments overestimates them. In both cases, however, the relative changes are in the right directions, causing the weighted correlation coefficients to be fairly high, 0.794 and 0.960 . The model also does a fair, but not impressive, job in tracking changes in production, failing notably in the case of basic industry. The decline in basic industry in Spain seems to be part of a secular trend that has occurred throughout the 1980s but is not accounted for in the model.

The performance of the model in tracking major macroeconomic variables, reported in Table 10, is, at first glance, spectacular. Much of the model's success in this direction, however, can 
be accounted for by simply remembering that the model predicted that the tax reform would result in a substantial increase in indirect taxes paid by consumers. It is worth pointing out that in 1985 this prediction of the model was controversial and was treated with considerable skepticism by a number of policymakers.

\section{Concluding Remarks}

A major challenge is to use the shortcomings of this model to develop a new version of the model more suitable for prediction. One obvious direction to take is to incorporate secular trends and to account for more exogenous shocks. What is surprising is how well the model does without doing this. Another is to come up with better elasticities in consumer demand functions and production functions. Another possibility is to use the changes that actually take place to calibrate certain parameters. Kehoe and Serra-Puche (1991), for example, use the change in imports that took place in Mexico between 1980 and 1983, in response to a sharp fall in the terms of trade, to calibrate the Armington elasticity of substitution between imports and domestic production in a similar model of the Mexican economy. The results in the previous section suggest many other possible improvements in the model: that the fall in the price of petroleum was not passed on to purchasers of energy products to the extent our model predicts, for example, might indicate that our assumption of perfect competition in this market should be modified.

Another obvious challenge is to figure out what types of policy changes or exogenous shocks this model is capable of analyzing and what types it is not. It probably comes as a surprise to some readers that the model does so well even though it takes intertemporal factors into account in very simplistic ways, if at all. Certainly, we would not expect the model to perform as well in evaluating

the impact of, say, a tax reform that significantly changes the tax rate on capital income. An interesting project would involve using a fully specified dynamic applied general equilibrium model, 
such as that of Auerbach and Kotlikoff (1987), Goulder and Summers (1989), or Jorgenson and Yun (1990), to analyze a policy change such as that analyzed here. The results of the dynamic model would then be compared with the results of the static model and with the actual data.

Another issue that we should mention is that of data availability. This is a constant limitation in this line of research. The reader will have noticed that throughout the analysis we have had to use a model calibrated to the 1980 SAM to analyze changes that took place six years later. Furthermore, it is only in 1990 that there was sufficient data to evaluate the performance of the model. In fact, the version of the model constructed in 1985 did not even utilize a complete SAM for 1980 (see Kehoe, Manresa, Noyola, Polo, Sancho, and Serra-Puche 1985b for the SAM that was used at the time). The later improvement in the SAM accounts for the differences in simulation results between, for example, Kehoe, Manresa, Noyola, Polo, Sancho and Serra-Puche (1985a), and Kehoe, Manresa, Noyola, Polo, and Sancho (1989). The basic predictions concerning consumer prices and major macroeconomic variables were present, however, even in earliest version of the model. Obviously, the model improves with more and better (for example, more recent) data. How much data do we need, and how good does it have to be, to have confidence in our simulation results? This paper brings us one step further to answering these questions. More work remains to be done. 


\section{References}

Andrés, J.; Dolado, J. J.; Molinas, C.; Sebastián, M.; and Zabalza, A. 1988. The influence of demand and capital constraints on Spanish unemployment. Working Paper SGPE-D-88005. Ministerio de Economía y Hacienda.

Armington, P. 1969. A theory of demand for products distinguished by place of production. IMF Staff Papers 16, 159-78.

Arrow, K. J., and Debreu, G. 1954. Existence of equilibrium for a competitive economy. Econometrica 22, 265-90.

Arrow, K. J., and Kehoe, T. J. 1994. Distinguished fellow: Herbert Scarf's contributions to economics. Journal of Economic Perspectives 8, 161-81.

Auerbach, A. J., and Kotlikoff, L. J. 1987. Dynamic fiscal policy. Cambridge: Cambridge University Press.

Ballard, C. L., and Goulder, L. H. 1985. Consumption taxes, foresight, and welfare: A computable general equilibrium analysis. In New developments in applied general equilibrium analysis, ed. J. Piggott and J. Whalley, pp. 253-282. Cambridge: Cambridge University Press.

Bergman, L.; Jorgenson, D. W.; and Zalai, E., eds. 1990. General equilibrium modeling and economic policy analysis. Oxford: Basil Blackwell.

Cox, D., and Harris, R. 1985. Trade liberalization and industrial organization: Some estimates for Canada. Journal of Political Economy 93: 115-45.

Dervis, K.; de Melo, J.; and Robinson, S. 1982. General equilibrium models for development policy. Cambridge: Cambridge University Press.

Dixon, P. B.; Parmenter, B. R.; Powell, A. A.; and Wilcoxen, P. J. 1992. Notes and problems in applied general equilibrium economics. Amsterdam: North-Holland. 
Dixon, P. B.; Parmenter, B. R.; Sutton, J.; and Vincent, D. P. 1982. ORANI: A multisectoral model of the Australian economy. Amsterdam: North-Holland.

Fullerton, D.; Shoven, J. B.; and Whalley, J. 1983. Replacing the U.S. income tax with a progressive consumption tax: A sequenced general equilibrium approach. Journal of Public Economics 20, 3-23.

Ginsburgh, V. 1994. In the Cournot-Walras general equilibrium model, there may be "more to gain" by changing the numéraire than by eliminating imperfections: A two-good economy example. In Applied general equilibrium and economic development, ed. J. Mercenier and T. N. Srinivasan, pp. 217-24. Ann Arbor: University of Michigan Press.

Goulder, L. H., and Summers, L. H. 1989. Tax policy, asset prices, and growth: A general equilibrium analysis. Journal of Public Economics 38, 265-96.

Harris, R. 1984. Applied general equilibrium analysis of small open economies with scale economies and imperfect competition. American Economic Review 74: 1016-32.

Harberger, A. C. 1962. The incidence of the corporate income tax. Journal of Political Economy $70,215-40$.

Johansen, L. 1960. A multi-sectoral study of economic growth. Amsterdam: North Holland.

Jorgenson, D. W. 1984. Econometric methods for applied general equilibrium analysis. In Applied general equilibrium analysis, ed. H. E. Scarf and J. B. Shoven, pp. 139-203. Cambridge: Cambridge University Press.

Jorgenson, D. W., and Yun, K.-Y. 1990. Tax policy and U.S. economic growth. In General equilibrium modeling and economic policy analysis, ed. L. Bergman, D. W. Jorgenson, and E. Zalai. Oxford: Basil Blackwell. 
Kehoe, P. J., and Kehoe, T. J. 1994. A primer on static applied general equilibrium models. Federal Reserve Bank of Minneapolis Quarterly Review 18 (2): 2-16.

Kehoe, P. J., and Kehoe, T. J., eds. 1995. In Modeling North American economic integration. Boston: Kluwar Academic Publishers.

Kehoe, T. J.; Manresa, A.; Noyola, P. J.; Polo, C.; and Sancho, F. 1988. A general equilibrium analysis of the 1986 tax reform in Spain. European Economic Review 32: 334-42.

Kehoe, T. J.; Manresa, A.; Noyola, P. J.; Polo, C.; Sancho, F.; and Serra-Puche, J. 1985a. Modelos de equilibrio general aplicado (MEGA): Un análisis del impacto del impuesto sobre el valor añadido (IVA) sobre la economía Española. Unpublished manuscript. Instituto de Estudios Fiscales.

Kehoe, T. J.; Manresa, A.; Noyola, P. J.; Polo, C.; Sancho, F.; and Serra-Puche, J. 1985b. A social accounting system for Spain: 1980. Working Paper 63.86. Departament d'Economia i d'Història Econòmica, Universitat Autònoma de Barcelona.

Kehoe, T. J.; Manresa, A.; Noyola, P. J.; Polo, C.; Sancho, F.; and Serra-Puche, J. 1986a. A general equilibrium analysis of the indirect tax reform in Spain. Working Paper 66.86. Departament d'Economia i d'Història Econòmica Universitat Autònoma de Barcelona.

Kehoe, T. J.; Manresa, A.; Noyola, P. J.; Polo, C.; Sancho, F.; and Serra-Puche, J. 1986b. Política econòmica i equilibri general. Quins són els efectes de l'IVA? Revista Econòmica de Catalunya 2: 76-81.

Kehoe, T. J.; Manresa, A.; Polo, C.; and Sancho, F. 1988. Una matriz de contabilidad social de la economía española. Estadística Española 30: 5-33.

Kehoe, T. J.; Manresa, A.; Polo, C.; Sancho, F. 1989. Un análisis de equilibrio general de la reforma fiscal de 1986 en España. Investigaciones Económicas 13: 337-85. 
Kehoe, T. J.; Polo, C.; and Sancho, F. 1995. An evaluation of the performance of an applied general equilibrium model of the Spanish economy. Economic Theory 6, 115-41.

Kehoe, T. J., and Serra-Puche, J. 1983. A computational general equilibrium model with endogenous unemployment: An analysis of the 1980 fiscal reform in Mexico. Journal of Public Economics 22: 1-26.

Kehoe, T. J., and Serra-Puche, J. 1991. A general equilibrium appraisal of energy policy in Mexico. Empirical Economics 16: 71-93.

Kuznets, S. 1937. Natural income and capital formation, 1919-1935. New York: National Bureau of Economic Research.

Keynes, J. M. 1940. How to pay for the war. London: Macmillan.

Leontief, W. W. 1941. The structure of American economy, 1919-1929: An empirical application of equilibrium analysis. Cambridge, Mass.: Harvard University Press.

Manne, A. S., ed. 1985. Economic equilibrium: Model formulation and solution. Mathematical Programming Study 23. Amsterdam: North-Holland.

McKenzie, L. 1959. On the existence of general equilibrium for a competitive market. Econometrica 27, 54-71.

Meade, J. E., and Stone, J. R. N. 1941. The construction of tables of national income, expenditure, savings, and investment. Economic Journal 51, 216-33.

Mercenier, J., and Srinivasan, T. N., eds. 1994. Applied general equilibrium and economic development. Ann Arbor: University of Michigan Press.

Mansur, A. H., and Whalley, J. 1984. Numerical specification of applied general equilibrium models: Estimation, calibration, and data. In Applied general equilibrium analysis, ed. H. E. Scarf and J. B. Shoven, pp. 69-127. Cambridge: Cambridge University Press. 
Piggott, J., and Whalley, J., eds. 1985. New developments in applied general equilibrium analysis. Cambridge: Cambridge University Press.

Quesnay, F. 1759. Tableau économique. Third edition. Paris: Privately printed. Reproduced, edited, and translated by M. Kuczynski and R. L. Meek 1972. Quesnay's tableau économique. London: Macmillan.

Pyatt, G., and Round, J. I., eds. 1985. Social account matrices: A basis for planning. Washington: The World Bank.

Scarf, H. E. 1967. On the computation of equilibrium prices. In Ten economic studies in the tradition of Irving Fischer, ed. W. J. Fellner, pp. 207-30. New York: Wiley.

Scarf, H. E., with Hansen, T. 1973. The computation of economic equilibria. New Haven: Yale University Press.

Scarf, H. E., and Shoven, J. B. 1984. Applied general equilibrium analysis. Cambridge: Cambridge University Press.

Shiells, C. R.; Stern, R. M.; and Deardorff, A. V. 1986. Estimates of the elasticities of substitution between imports and home goods for the United States. Weltwirtschaftliches-Archiv 122, 497-519.

Shoven, J. B., and Whalley J. 1972. A general equilibrium calculation of the effects of differential taxation of income from capital in the U.S. Journal of Public Economics 1: 281-321.

Shoven, J. B., and Whalley J. 1984. Applied general equilibrium models of taxation and international trade: An introduction and survey. Journal of Economic Literature 22: 1007-51.

Shoven, J. B., and Whalley J. 1992. Applying general equilibrium. Cambridge: Cambridge University Press.

Srinivasan, T. N., and Whalley, J., eds. 1986. General equilibrium trade policy modeling. Cambridge, Mass.: MIT Press. 
Stone, R. 1947. Measurement of national income and the construction of social accounts. Geneva: United Nations.

Stone, R. 1985. The disaggregation of the household sector in the national accounts. In Social accounting matrices: A basis for planning, ed. G. Pyatt and J. I. Round, pp. 145-85. Washington: The World Bank.

Stone, R. 1986. The accounts of society. Journal of Applied Econometrics 1, 5-28.

Studenski, P. 1958. The income of nations. New York: New York University Press.

Taylor, L., ed. 1990. Socially relevant policy analysis: Structuralist computable general equilibrium models for the developing world. Cambridge, Mass.: MIT Press.

United Nations. 1953. A system of national accounts and supporting tables. New York: United Nations.

United Nations. 1968. A system of national accounts. New York: United Nations.

Whalley, J. 1986. What have we learned from general equilibrium tax policy models? Working Paper 8625C. University of Western Ontario.

Whalley, J. 1988. Lessons from general equilibrium models. In Uneasy compromise: Problems of a hybrid income-consumption tax, ed. H. J. Arron, H. Galper, and J. A. Pechman, pp. 15-50. Washington: Brookings Institute. 
Table 1

Sectors in the Aggregated 1980 Social Accounting Matrix for Spain

$\underline{\text { Producer Goods }}$

1. Primaries

$\left(1-2^{1}\right)$

2. Manufacturing

$(3-7)$

3. Construction and Services

$(8-12)$

Consumer Goods

4. Food and Beverages

$(17-18)$

5. Clothing, Housing, and Household Articles

6. Services

Factors of Production

7. Labor

(26-27)

8. Capital

Institutions

9. Low-Income Households

(I,III,V,VII)

10. High-Income Households

(II,IV,VI,VIII)

11. Government

$(13$, IX)

11a. Direct Taxes

11b. Indirect Taxes and Tariffs

Capital Account

12. Investment

Foreign Sector

13. Rest of the World

$(15-16, X-X I)$

${ }^{1}$ Corresponding sectors in Kehoe, Manresa, Polo, and Sancho (1988). 
Table 2

Aggregated 1980 Social Accounting Matrix for Spain

(In Trillion 1980 Pesetas $^{1}$ )

\begin{tabular}{|c|c|c|c|c|c|c|c|c|c|c|c|c|c|c|c|}
\hline & & \multicolumn{14}{|c|}{ EXPENDITURES } \\
\hline & & 1 & 2 & 3 & 4 & 5 & 6 & 7 & 8 & 9 & 10 & 11 & 12 & 13 & Total \\
\hline & 1 & 2 & 1 & 1 & 1 & 1 & 0 & & & & & & 0 & 0 & 6 \\
\hline & 2 & 1 & 4 & 1 & 1 & 1 & 1 & & & & & & 1 & 2 & 12 \\
\hline & 3 & 0 & 1 & 3 & 1 & 2 & 3 & & & & & 2 & 2 & 0 & 14 \\
\hline $\mathrm{R}$ & 4 & & & & & & & & & 2 & 1 & & & & 3 \\
\hline $\mathrm{E}$ & 5 & & & & & & & & & 2 & 2 & & & & 4 \\
\hline $\mathrm{C}$ & 6 & & & & & & & & & 2 & 2 & & & & 4 \\
\hline $\mathrm{E}$ & 7 & 1 & 2 & 3 & & & & & & & & & & & 6 \\
\hline I & 8 & 1 & 1 & 5 & & & & & & & & & & & 7 \\
\hline $\mathrm{P}$ & 9 & & & & & & & & 2 & & & 1 & & 0 & 7 \\
\hline $\mathrm{T}$ & 10 & & & & & & & 2 & 5 & & & 0 & & 0 & 7 \\
\hline S & 11 & 0 & 1 & 1 & 0 & 0 & 0 & & 0 & 0 & 1 & & & & 3 \\
\hline & $11 \mathrm{a}$ & & & & & & & & & 0 & 1 & & & & 1 \\
\hline & $11 \mathrm{~b}$ & 0 & 1 & 1 & 0 & 0 & 0 & & & & & & & & 2 \\
\hline & 12 & & & & & & & & & 1 & 1 & 0 & & 1 & 3 \\
\hline & 13 & 1 & 2 & 0 & & & & & 0 & & & & & & 3 \\
\hline Total & & 6 & 12 & 14 & 3 & 4 & 4 & 6 & 7 & 7 & 7 & 3 & 3 & 3 & \\
\hline
\end{tabular}

Source: Kehoe, Manresa, Polo, and Sancho (1988).

${ }^{1}$ U.S. trillions, British/Spanish billions; 0 represents a nonzero number that has been rounded down to zero. 


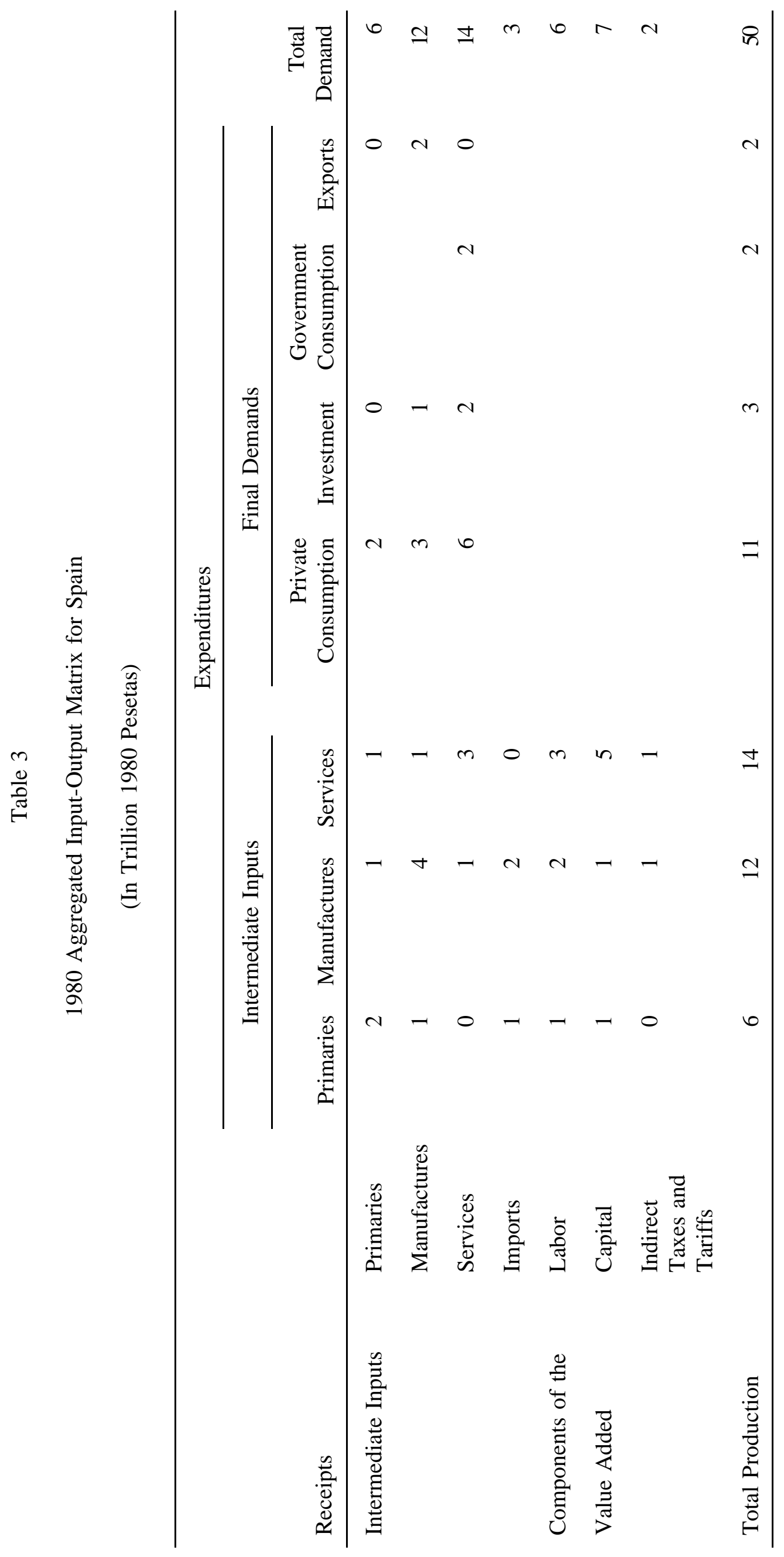


Table 4

1980 National Income and Product Accounts for Spain

(In Trillion 1980 Pesetas)

\begin{tabular}{|c|c|c|c|}
\hline \multicolumn{2}{|l|}{ Expenditures } & \multicolumn{2}{|l|}{ Income } \\
\hline Private Consumption & 11 & Wages and Salaries & 6 \\
\hline Private Investment & 2 & Other Factor Payments & 7 \\
\hline Government Consumption & 2 & Indirect Taxes and Tariffs & 2 \\
\hline Government Investment & 1 & & \\
\hline Exports & 2 & & \\
\hline - Imports & -3 & & \\
\hline Gross Domestic Product & 15 & Gross Domestic Product & 15 \\
\hline Government Accounts & & Foreign Accounts & \\
\hline Government Consumption & 2 & Imports & 3 \\
\hline Government Investment & 1 & - Exports & -2 \\
\hline Government Transfers & 1 & & \\
\hline - Indirect Taxes and Tariffs & -2 & & \\
\hline - Direct Taxes & -1 & & \\
\hline Government Deficit & 1 & Trade Deficit & 1 \\
\hline
\end{tabular}


Table 5

List of Sectors in Disaggregated 1980 Social Accounting Matrix for Spain

\begin{tabular}{lll}
\hline \hline & \multicolumn{2}{c}{ Production Goods } \\
\hline \multicolumn{2}{l}{ Model } & Input-Output Table ${ }^{1}$ \\
\hline 1. & Agriculture & $1-4$ \\
2. & Energy & $5-9$ \\
3. & Basic Industry & $10-23$ \\
4. & Machinery & $24-29,31-34$ \\
5. & Automobile Industry & 30 \\
6. & Food Products & $35-49$ \\
7. & Other Manufacturing & $50-62$ \\
8. & Construction & 63 \\
9. & Commerce & $64-66$ \\
10. & Transportation & $67-73$ \\
11. Services & $74-81,85(1 / 2)$ \\
12. & Government Services & $82-84,85(1 / 2)$ \\
& & Nonconsumption Demand
\end{tabular}

13. Government Consumption 88

14. Investment and Inventory Accumulation 90-91

15. Exports to the European Community 93

16. Exports to the Rest of the World 93

Consumption Goods

\begin{tabular}{|c|c|c|}
\hline \multicolumn{2}{|c|}{ Model } & \multirow{2}{*}{$\begin{array}{l}\text { Consumer Expenditure Survey } \\
111-121\end{array}$} \\
\hline 17. & Food and Nonalcoholic Beverages & \\
\hline 18. & Tobacco and Alcoholic Beverages & $131,141,142$ \\
\hline 19. & Clothing & $211-222$ \\
\hline 20. & Housing & $311-324$ \\
\hline 21. & Household Articles & $411-461$ \\
\hline 22. & Medical Services & $511-551$ \\
\hline 23. & Transportation & $611-642$ \\
\hline 24. & Recreational Services & $711-741$ \\
\hline 25. & Other Services & $811-924$ \\
\hline \multicolumn{3}{|c|}{ Factors of Production } \\
\hline 26. & Unskilled Labor & \\
\hline 27. & Skilled Labor & \\
\hline 28. & Capital and Other Factors & \\
\hline
\end{tabular}


(Table 5, continued)

${ }^{1}$ Corresponding categories in Contabilidad Nacional de España, Base 1980, Cuentas Nacionales y Tabla Input-Output.

${ }^{2}$ Corresponding categories in Encuesta de Presupuestos Familiares, 1980-81. 
Table 6

List of Institutions in Disaggregated 1980 Social Accounting Matrix for Spain

\begin{tabular}{|c|c|c|}
\hline \multicolumn{3}{|c|}{ Households } \\
\hline Age of Household Head & 1980 Income & $\begin{array}{l}\text { Education of } \\
\text { Household Head }\end{array}$ \\
\hline I. 24 years or less & less than 700,000 pesetas & \\
\hline II. 24 years or less & more than 700,000 pesetas & \\
\hline III. between 25 and 65 years & less than $1,000,000$ pesetas & no higher \\
\hline IV. between 25 and 65 years & more than $1,000,000$ pesetas & no higher \\
\hline V. between 25 and 65 years & less than $1,000,000$ pesetas & some higher \\
\hline VI. between 25 and 65 years & more than $1,000,000$ pesetas & some higher \\
\hline VII. 66 years or more & less than 700,000 pesetas & \\
\hline VIII. 66 years or more & more than 700,000 pesetas & \\
\hline
\end{tabular}

\section{Other Institutions}
IX. Government
X. Rest of European Community
XI. Rest of World 
Table 7

Spanish Model Results

Consumer Prices

(Percentage Change ${ }^{1}$ )

\begin{tabular}{|c|c|c|c|c|}
\hline Sector & $\begin{array}{c}\text { Actual } \\
1986 / 1985^{2}\end{array}$ & $\begin{array}{c}\text { Model } \\
\text { Policy Only }\end{array}$ & $\begin{array}{c}\text { Model } \\
\text { Shocks Only }\end{array}$ & $\begin{array}{c}\text { Model } \\
\text { Policy and } \\
\text { Shocks }\end{array}$ \\
\hline 17. Food and Nonalcoholic Beverages & 1.8 & -2.3 & 4.0 & 1.7 \\
\hline 18. Tobacco and Alcoholic Beverages & 3.9 & 2.5 & 3.1 & 5.8 \\
\hline 19. Clothing & 2.1 & 5.6 & .9 & 6.6 \\
\hline 20. Housing & -3.2 & -2.2 & -2.7 & -4.8 \\
\hline 21. Household Articles & .1 & 2.2 & .7 & 2.9 \\
\hline 22. Medical Services & -.7 & -4.8 & 6 & -4.2 \\
\hline 23. Transportation & -4.0 & 2.6 & -8.8 & -6.2 \\
\hline 24. Recreation & -1.4 & -1.3 & 1.4 & .1 \\
\hline 25. Other Services & 2.9 & 1.1 & 1.7 & 2.8 \\
\hline Change in Consumer Price Index & 8.4 & .0 & .0 & .0 \\
\hline Weighted Correlation with $1986 / 1985^{4}$ & 1.000 & -.079 & .872 & .936 \\
\hline Prediction $\mathrm{R}^{2}$ for $1986 / 1985^{5}$ & 1.000 & -.995 & .226 & .657 \\
\hline
\end{tabular}

${ }^{1}$ Change in sectoral price index deflated by the consumer price index. The weights used are the consumption shares (1) 0.2540, (2) 0.0242, (3) 0.0800, (4) 0.1636, (5) 0.0772, (6) 0.0376, (7) 0.1342, (8) 0.0675, and (9) 0.1617.

${ }^{2}$ Actual data are derived from Indice de Precios de Consumo, Boletin Trimestral, Octubre-Diciembre 1987 and OctubreDiciembre 1987. See Kehoe, Polo, and Sancho (1995) for details.

${ }^{3}$ The input requirements of all inputs in the agricultural sector, except imports, are divided by 0.9227 . The price of energy imports is multiplied by 0.5240 .

${ }^{4}$ Weighted correlation coefficients with actual changes 1986/1985. The weights are the same as those in Footnote 1.

${ }^{5}$ Weighted $\mathrm{R}^{2}$ in predicting actual changes $1986 / 1985$. The weights are the same as those in Footnote 1 . 
Table 8

Spanish Model Results

Industrial Prices

(Percentage Change $^{1}$ )

\begin{tabular}{|c|c|c|c|c|c|}
\hline & & $\begin{array}{c}\text { Actual } \\
1986 / 1985^{2}\end{array}$ & $\begin{array}{c}\text { Model } \\
\text { Policy Only }\end{array}$ & $\begin{array}{c}\text { Model } \\
\text { Shocks Only }\end{array}$ & $\begin{array}{c}\text { Model } \\
\text { Policy and } \\
\text { Shocks }\end{array}$ \\
\hline 1. & Agriculture & -.3 & -6.0 & 8.0 & 1.6 \\
\hline 2. & Energy & -17.9 & -7.5 & -32.8 & -37.8 \\
\hline 3. & Basic Industry & -8.5 & -6.2 & -3.1 & -9.1 \\
\hline 4. & Machinery & -3.1 & -6.5 & -.1 & -6.6 \\
\hline 5. & Automobiles & -1.2 & -3.9 & .0 & -3.9 \\
\hline 6. & Food Processing & -4.1 & -6.4 & 4.0 & -2.7 \\
\hline 7. & Other Manufacturing & -4.3 & -5.7 & .5 & -5.1 \\
\hline 8. & Construction & -.6 & -6.1 & .0 & -6.0 \\
\hline \multicolumn{2}{|c|}{ Change in Consumer Price Index } & 8.4 & .0 & .0 & .0 \\
\hline \multicolumn{2}{|c|}{ Change in Industrial Price Index } & 2.1 & -6.3 & -3.9 & -9.7 \\
\hline \multicolumn{2}{|c|}{ Weighted Correlation with $1986 / 1985^{4}$} & 1.000 & .794 & .840 & .960 \\
\hline \multicolumn{2}{|c|}{ Prediction $\mathrm{R}^{2}$ for $1986 / 1985^{5}$} & 1.000 & .627 & .146 & .046 \\
\hline
\end{tabular}

${ }^{1}$ Change in sectoral price index deflated by the consumer price index.

${ }^{2}$ Actual data are derived from Boletin Trimestral de Coyuntura, Septiembre 1990. See Kehoe, Polo, and Sancho (1995) for details.

${ }^{3}$ See Footnote 3 for Table 3.

${ }^{4}$ Weighted (uncentered) correlation coefficient with actual changes 1986/1985. The weights used are value of total production shares, (1) 0.1110 , (2) 0.1487 , (3) 0.1695 , (4) 0.1281 , (5) 0.0443 , (6) 0.1447 , (7) 0.1326, and (8) 0.1211 .

${ }^{5}$ Weighted $\mathrm{R}^{2}$ in predicting actual changes $1986 / 1985$. The weights are the same as those in Footnote 1 . 
Table 9

Spanish Model Results

Industrial Activity Levels

(Percentage Change ${ }^{1}$ )

\begin{tabular}{|c|c|c|c|c|c|}
\hline & & $\begin{array}{c}\text { Actual } \\
1986 / 1985^{2}\end{array}$ & $\begin{array}{c}\text { Model } \\
\text { Policy Only }\end{array}$ & $\begin{array}{c}\text { Model } \\
\text { Shocks Only }\end{array}$ & $\begin{array}{c}\text { Model } \\
\text { Policy and } \\
\text { Shocks }\end{array}$ \\
\hline 2. & Energy & -2.7 & -2.3 & 3.1 & .4 \\
\hline 3. & Basic Industry & -4.5 & 1.4 & -.6 & .8 \\
\hline 4. & Machinery & 5.8 & 4.0 & -1.0 & 3.1 \\
\hline 5. & Automobiles & 5.5 & 1.2 & 2.6 & 3.7 \\
\hline 6. & Food Processing & -4.2 & -2.3 & -1.3 & -3.8 \\
\hline 7. & Other Manufacturing & 1.9 & -2.4 & -.3 & -2.8 \\
\hline \multicolumn{2}{|c|}{ Industrial Output Index } & 3.5 & -.2 & 2.0 & 1.8 \\
\hline \multicolumn{2}{|c|}{ Weighted Correlation with $1986 / 1985^{4}$} & 1.000 & .443 & -.193 & .389 \\
\hline \multicolumn{2}{|c|}{ Prediction $\mathrm{R}^{2}$ for $1986 / 1985^{5}$} & 1.000 & .155 & -.225 & .104 \\
\hline
\end{tabular}

${ }^{1}$ Change in sectoral industrial production index deflated by industrial output index. The weight used are the value added shares, (2) 0.1506, (3) 0.2108, (4) 0.2172, (5) 0.0511, (6) 0.1431, and (7) 0.2271.

${ }^{2,3}$ See Footnotes 2 and 3 for Table 3.

${ }^{4}$ Weighted correlation coefficient with actual changes 1986/1985. The weights are the same as those in Footnote 1.

${ }^{5}$ Weighted $\mathrm{R}^{2}$ in predicting actual changes $1986 / 1985$. The weights are the same as those in Footnote 1. 


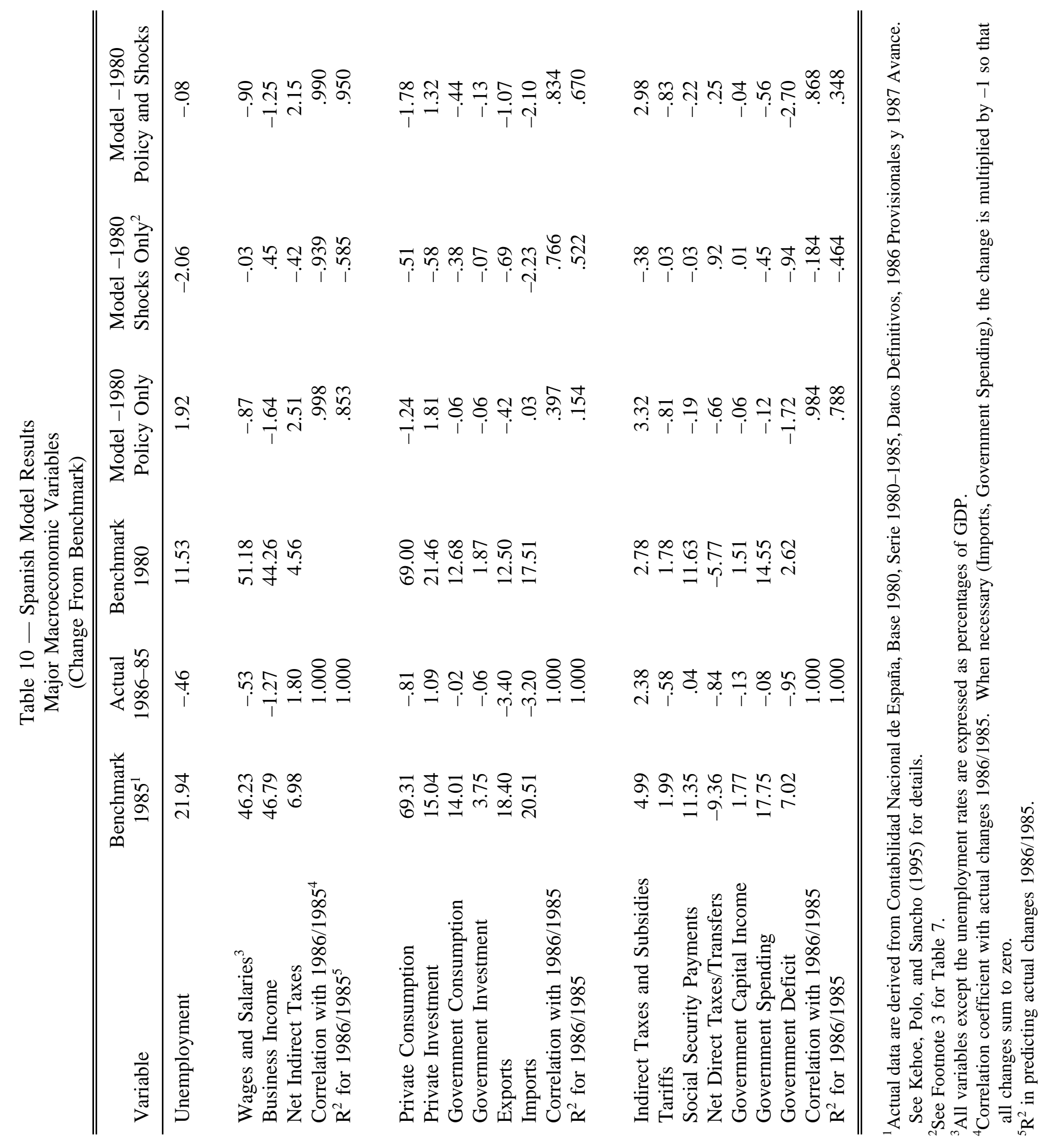

